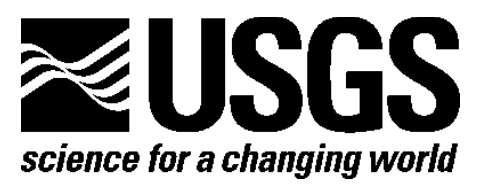

Prepared in cooperation with the National Park Service

\title{
Water-Quality Data of Soil Water from Three Watersheds, Shenandoah National Park, Virginia 1999-2000
}

By Karen C. Rice, Suzanne W. Maben, and James R. Webb

Open-File Report 01-236

U.S. Department of the Interior

U.S. Geological Survey 
U.S. Department of the Interior

U.S. Geological Survey

\section{Water-Quality Data of Soil W ater from Three \\ Watersheds, Shenandoah National Park, Virginia, 1999-2000}

By Karen C. Rice ${ }^{1}$, Suzanne W. Maben ${ }^{2}$, and James R. Webb²

${ }^{1}$ U.S. Geological Survey

2University of Virginia

Open-File Report 01-236

Prepared in cooperation with the

National Park Service

Richmond, Virginia

2001 


\section{U.S. DEPARTMENT OF THE INTERIOR \\ GALE A. NORTON, Secretary}

U.S. GEOLOGICAL SURVEY

Charles G. Groat, Director

The use of trade or product names in this report is for identification

purposes only and does not constitute endorsement by the

U.S. Geological Survey.

For additional information write to:

District Chief

U.S. Geological Survey

1730 East Parham Road

Richmond, VA 23228

dc_va@usgs.gov
Copies of this report can be purchased from:

U.S. Geological Survey

Branch of Information Services

Box 25286, Federal Center

Denver, CO 80225-0286 


\section{CONTENTS}

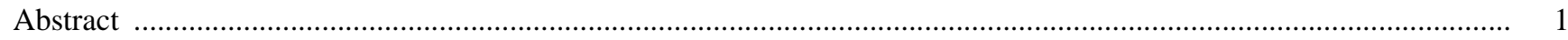

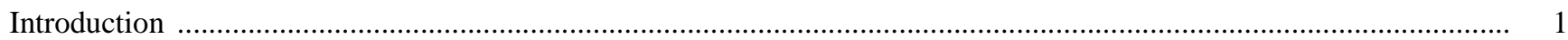

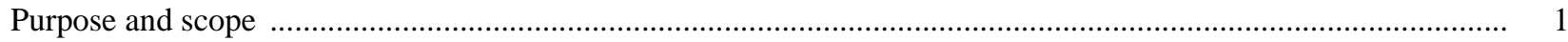

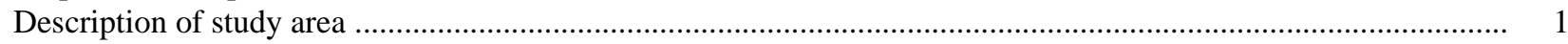

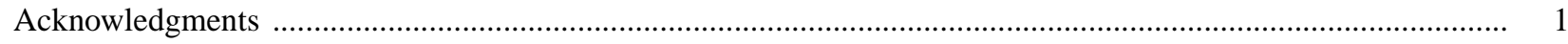

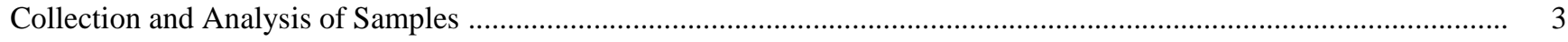

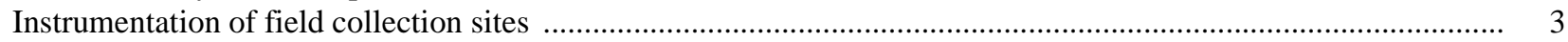

Field data-collection methods ................................................................................................................ 3

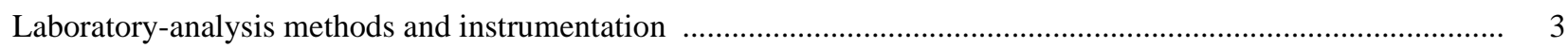

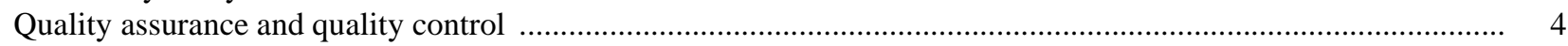

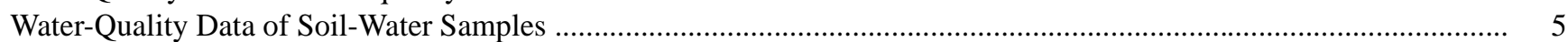

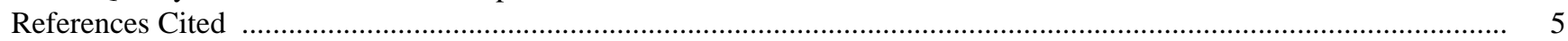

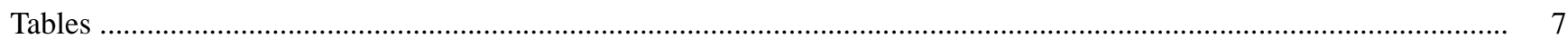

\section{FIGURE}

1. Lysimeter sites in three watersheds in Shenandoah National Park, Virginia ......................................................... 2

\section{TABLES}

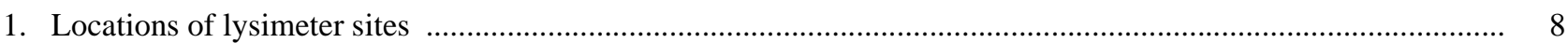

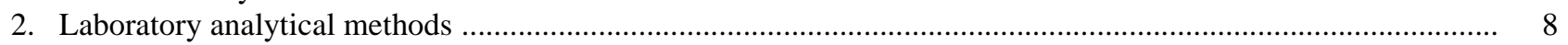

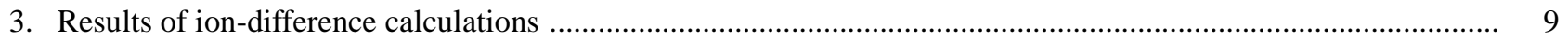

4. Results of analysis of natural-matrix reference samples (FN09 and FN10) …................................................. 12

5. Results of analysis of synthetic-matrix reference samples (EPA1) …........................................................... 12

6. Results of laboratory-split analyses of selected soil-water samples ............................................................. 13

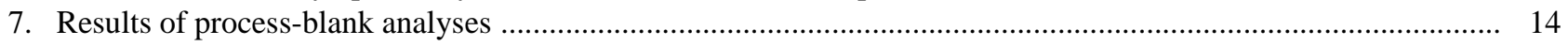

8. Results for National Water Research Institute interlaboratory quality-assurance studies ................................... 14

9. Water-quality data of soil-water samples collected from Paine Run watershed, Shenandoah National Park, Virginia, 1999-2000

10. Water-quality data of soil-water samples collected from Staunton River watershed, Shenandoah National Park, Virginia, 1999-2000

11. Water-quality data of soil-water samples collected from Piney River watershed, Shenandoah National Park, Virginia, 1999-2000 


\section{CONVERSION FACTORS AND ABBREVIATED WATER-QUALITY UNITS}

\begin{tabular}{rcll}
\hline Multiply & & By & To obtain \\
& & Length & \\
inch (in.) & 25,400 & micrometer \\
inch (in.) & 25.4 & millimeter \\
inch (in.) & 2.54 & centimeter \\
foot (ft.) & 0.3048 & meter \\
& Area & \\
mile (mi) & 1.609 & kilometer \\
square mile (mi ${ }^{2}$ ) & 2.590 & square kilometer \\
& $\underline{\text { Volume }}$ & \\
ounce, fluid (fl. oz) & 29,570 & microliter \\
ounce, fluid (fl. oz) & 29.57 & milliliter \\
ounce, fluid (fl. oz) & 0.02957 & liter \\
pint (pt) & 0.4732 & liter \\
quart (qt) & 0.9464 & liter \\
gallon (gal) & 3.785 & liter \\
\hline
\end{tabular}

Water temperature is reported in degrees Celsius $\left({ }^{\circ} \mathrm{C}\right)$, which can be converted to degree Fahrenheit $\left({ }^{\circ} \mathrm{F}\right)$ as follows: ${ }^{\circ} \mathrm{F}=1.8\left({ }^{\circ} \mathrm{C}\right)+32^{\circ}$

Abbreviated water-quality units: Chemical concentration is reported in micrograms per liter $(\mu \mathrm{g} / \mathrm{L})$, microequivalents per liter ( $\mu$ eq/L), or micromoles per liter $(\mu \mathrm{mol} / \mathrm{L})$. Micrograms per liter is a unit expressing the concentration of chemical constituents in solution as mass (micrograms) of solute per unit volume (liter) of solution. One thousand micrograms per liter is equivalent to one milligram per liter. For concentrations less than $7,000 \mathrm{mg} / \mathrm{L}$, the numerical value is the same as for concentrations in parts per million. Microequivalents per liter is a unit expressing the concentration of chemical constituents in solution as charge equivalents of solute per unit volume (liter) of solution. One thousand microequivalents per liter is equal to one milliequivalent per liter. Micromoles per liter is a unit expressing the concentration of chemical constituents in solution as moles of solute per unit volume (liter) of solution. One thousand micromoles per liter is equal to one millimole per liter. Specific electrical conductance of water is reported in microsiemens per centimeter at 25 degrees Celsius ( $\mu \mathrm{S} / \mathrm{cm})$. 


\title{
Water-Quality Data of Soil Water from Three Watersheds, Shenandoah National Park, Virginia, 1999-2000
}

\author{
By Karen C. Rice, Suzanne W. Maben, and James R. Webb
}

\begin{abstract}
Data on the chemical composition of soilwater samples were collected quarterly from three watersheds in Shenandoah National Park, Virginia, from September 1999 through July 2000. The soilwater samples were analyzed for specific conductance and concentrations of sodium, potassium, calcium, magnesium, ammonium, chloride, nitrate, sulfate, acid-neutralizing capacity, silica, and total monomeric aluminum. The soil-water data presented in this report can be used to support water-quality modeling of the response of streams to episodic acidification. Laboratory analytical data as well as laboratory quality-assurance information also are presented.
\end{abstract}

\section{INTRODUCTION}

This report presents data for soil-water samples that were collected by the U.S. Geological Survey (USGS) from three watersheds in Shenandoah National Park, Virginia, as part of the interagency Water-Quality Partnership Program with the National Park Service. As part of this partnership, which began in 1998, USGS is performing high-priority water-quality work on National Park lands. The soil-water data presented in this report can be used to support water-quality modeling of the response of streams to episodic acidification. The soil-water samples were analyzed for specific conductance and concentrations of sodium, potassium, calcium, magnesium, ammonium, chloride, nitrate, sulfate, acid-neutralizing capacity, silica, and total monomeric aluminum.

\section{Purpose and scope}

The purpose of this report is to present data on the chemical composition of soil-water samples that were collected approximately quarterly from three watersheds in Shenandoah National Park, Virginia, from September 1999 through July 2000. The instrumentation and methods used to collect soil-water samples and the methods and quality assurance for laboratory analyses of the samples are described. Locations of the lysimeter sites, laboratory methods, quality-assurance results, and data from the water-quality analyses of the soil-water samples are presented in tables.

\section{Description of study area}

Shenandoah National Park is located in the Blue Ridge Physiographic Province in north-central Virginia. The Park straddles the crest of the Blue Ridge Mountains along a 112-km segment stretching from Front Royal in the north to Waynesboro in the south (Gathright, II, 1976). Three watersheds that represent a gradient in acidity of streamwater were selected for this study. The three streams, from most acidic to least acidic, are Paine Run, Staunton River, and Piney River (fig. 1). The respective watershed areas are 12.4, 10.5, and $12.6 \mathrm{~km}^{2}$.

\section{Acknowledgments}

Appreciation is given to Shenandoah National Park personnel, in particular Christi Gordon and Shane Spitzer, for permission to install the lysimeters, for support of the study, and for assistance in conducting the study. The authors thank the following University of Virginia students and staff: Charles J. Fievet, Jr., and Cory Gray for assistance with installation of the lysimeters, Daniel L. Welsch for collection of the soil-water samples, and Frank A. Deviney, Jr., for database assistance. 


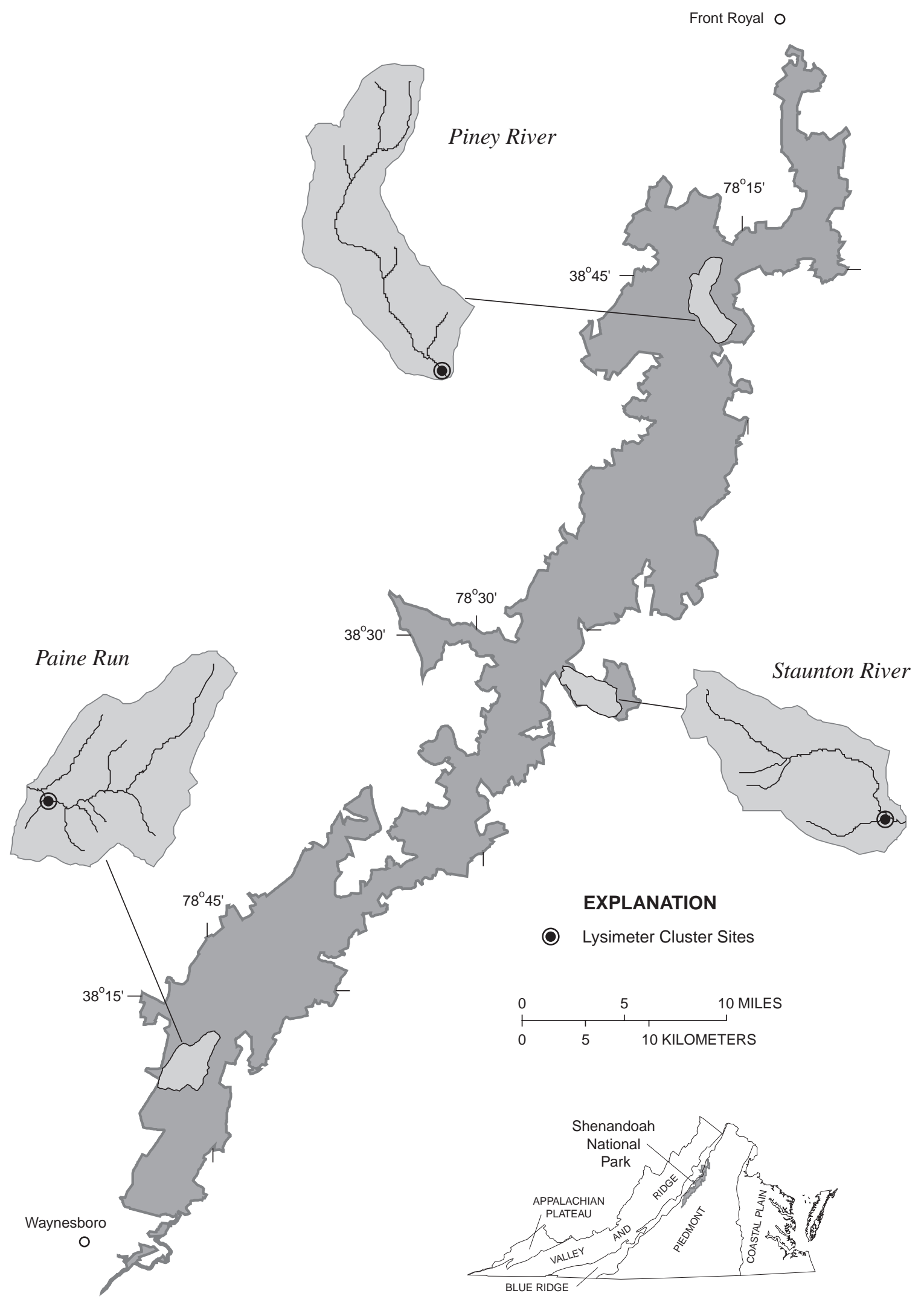

Figure 1. Lysimeter sites in three watersheds in Shenandoah National Park, Virginia. 


\section{COLLECTION AND ANALYSIS OF SAMPLES}

Soil-water samples were collected from the three watersheds approximately quarterly, starting in September 1999 and ending in July 2000. Lysimeters were installed during the summer of 1999. The lysimeters were allowed to equilibrate to the soil environment before the first samples were collected in September 1999. Additional samples were collected in January, April, and July 2000.

\section{Instrumentation of field collection sites}

Soil-water samples were collected by use of Soilmoisture Equipment Corp. suction lysimeters installed at three sites in each of the watersheds (table 1, at end of report). Lysimeters consisted of 4.8cm-diameter polyvinylchloride (PVC) tubes with a 5.7$\mathrm{cm}$-long, round-bottom, porous ceramic cup at the base. A Tygon sample-collection tube extended from the porous cup through a neoprene stopper at the top of each PVC tube. Sample-collection tubes were sealed with plastic pinch clamps. The porous ceramic cups had a 2-bar air entry and a maximum pore size of $1.3 \mu \mathrm{m}$.

At each site, three lysimeters were installed vertically at depths of approximately 36,66 , and $97 \mathrm{~cm}$ below land surface. Holes for the lysimeters were dug with hand augers, and rocks were removed by loosening with trowels, picks, and by hand. The porous-cup ends of the lysimeters were soaked in deionized water for several weeks prior to field installation and were kept submerged in the field until the lysimeters were transferred to the holes. Once the lysimeter was placed in the hole, the void space around the porous cup was backfilled with the native soil that was removed from the hole. Care was taken to tamp the soil down firmly around the porous ceramic cup to ensure an adequate soil contact with the cup. The rest of the hole was backfilled with native soil, which also was tamped firmly to prevent surface water from running down the augured hole.

\section{Field data-collection methods}

Approximately one week prior to sampling, a visit to the sites was made to place a vacuum on each lysimeter. The vacuum was created by pumping a handheld vacuum pump until the suction value no longer changed, as indicated by a gauge on the pump. Average vacuum achieved upon pumping was 70 centibars. The vacuum drew water from the soil matrix through the ceramic cup and into the lysimeter. Approximately one week after the vacuum was placed on the lysimeter, the soil-water sample was drawn to the surface through the sample tube by use of a hand pump and into a clear 250-mL high-density polyethylene collection bottle. Prior to collecting the sample, the collection bottles were washed with detergent and acid ( 2 normal hydrochloric acid) and rinsed multiple times with deionized water. The cleanliness of the bottle was checked by partially filling the bottle with deionized water, shaking, and testing the specific conductance of the deionized water. The bottles were considered clean when the specific conductance of the rinse water was less than $1.3 \mu \mathrm{S} / \mathrm{cm}$. The bottles were stored filled with deionized water. At the collection site, the deionized water was discarded and the sample bottle was rinsed with sample water, which was discarded before the rest of the sample was collected. Samples were transported in coolers with refrigerant to the laboratory.

\section{Laboratory-analysis methods and instrumentation}

In the laboratory, $0.5 \mathrm{~mL}$ of chloroform was added to the sample bottles to prevent microbial degradation of the samples. The unfiltered samples were analyzed for specific conductance (SC), sodium $\left(\mathrm{Na}^{+}\right)$, potassium $\left(\mathrm{K}^{+}\right)$, calcium $\left(\mathrm{Ca}^{2+}\right)$, magnesium $\left(\mathrm{Mg}^{2+}\right)$, ammonium $\left(\mathrm{NH}_{4}{ }^{+}\right)$, chloride $\left(\mathrm{Cl}^{-}\right)$, nitrate $\left(\mathrm{NO}_{3}{ }^{-}\right)$, sulfate $\left(\mathrm{SO}_{4}{ }^{2-}\right)$, acid-neutralizing capacity (ANC), silica $\left(\mathrm{SiO}_{2}\right)$, and total monomeric aluminum (Al) (McAvoy and others, 1992). All samples were kept at room temperature until chemical analysis was performed.

Analyses were conducted at the University of Virginia Shenandoah Watershed Study (SWAS) Laboratory, using instrumentation and methods summarized in table 2, at end of report. More detailed methods descriptions and the Standard Operation Procedure document for the SWAS laboratory are in the Laboratory Procedure Manual (University of Virginia, 1996). 


\section{Quality assurance and quality control}

Quality-assurance and quality-control information for analysis of soil-water samples by the SWAS laboratory was determined by calculation of percent ion difference; analyses of natural- and syntheticmatrix reference samples, laboratory split samples, and process blanks; and by participation in interlaboratory quality-assurance studies.

Percent ion differences were calculated for soilwater samples for which sufficient sample was available; these were calculated by comparing measured total anion and cation equivalents (eq) (all decimal places retained), as follows:

percent ion difference $=\frac{\text { sum of anion eq }- \text { sum of cation eq }}{\text { sum of anion eq }+ \text { sum of cation eq }} \times 100$

A percent ion difference close to zero generally indicates a complete ion analysis. Most of the soilwater samples have percent ion differences within 10 percent (table 3, at end of report). All but one of the samples has an excess of cations. A percent ion difference greater than 10 percent indicates the presence of unmeasured ions; in this study, the unmeasured ions likely are organic anions, which were not analyzed.

Natural- (FN09 and FN10) and synthetic-matrix (EPA1) reference samples also were analyzed for quality-assurance purposes. Reference samples FN09 and FN10 are performance-evaluation samples distributed and used as a part of the U.S. Environmental Protection Agency's Episode Response Project (USEPA ERP). Reference sample EPA1 is distributed by the USEPA Environmental Monitoring and Support Laboratory (Cincinnati, Ohio). Results of these analyses by the SWAS laboratory during the period July 1998 through June 1999 and comparisons to the target values are shown in tables 4 and 5 (at end of report).

Reference-sample values obtained by the SWAS laboratory were compared to the target values provided by the USEPA as an indication of accuracy (percent difference from target in tables 4 and 5). On the basis of the three reference samples, the accuracy of the laboratory results for $\mathrm{Na}^{+}, \mathrm{K}^{+}, \mathrm{Ca}^{2+}, \mathrm{Mg}^{2+}, \mathrm{NH}_{4}^{+}, \mathrm{Cl}^{-}$, $\mathrm{SO}_{4}{ }^{2-}$, and $\mathrm{SiO}_{2}$ in the soil-water samples is acceptable, because the percent difference from the target value is, at most, 8.4. The analyte values that show significant deviation from target values are concentrations of $\mathrm{NO}_{3}{ }^{-}$ (-25.7 percent) and $\mathrm{Al}$ (89.2 percent) for FN09 (table 4). If only the results for $\mathrm{NO}_{3}{ }^{-}$and $\mathrm{Al}$ were considered, the accuracy of the laboratory for these two analytes might be in question. Other indications of the laboratory's accuracy, however, are given by the results for FN10 (table 4) and EPA1 (table 5), as well as by results of interlaboratory quality-assurance studies (discussed later in the report). The acceptable performance of the laboratory for these analytes in FN10 indicates that the concentration of the two analytes in FN09 possibly has changed by degradation or alteration since collection and distribution of the reference samples by the USEPA ERP, which reported the target values in 1989.

Laboratory-split samples and process blanks also were analyzed for quality-assurance purposes. Results of laboratory-split analyses of selected soil-water samples are shown in table 6 (at end of report). Values obtained for laboratory-split analyses can be compared as an indication of analytical precision. The percent difference between analyses performed on split samples varied from a minimum of 0 to a maximum of 7.2. This indicates that the precision of analyses is acceptable. Results of process-blank analyses are shown in table 7 (at end of report). These results are one indication of whether analyte concentrations in the soil-water samples could have been compromised by collection, transport, storage, or analysis methods. The mean values for each analyte of the process-blank samples are near or below the minimum analytical detection limit (table 7). This demonstrates that there is no processing effect on the concentrations reported for the soil-water samples.

The SWAS laboratory also participates in interlaboratory quality-assurance studies administered by Environment Canada's National Water Research Institute (NWRI). Environmental programs in both the United States and Canada participate in these studies, which are designed for laboratories analyzing acid rain and surface waters. The purpose of these studies is to provide a useful means of quantifying laboratory performance and data quality. The report for each study includes an assessment of any systematic bias and indicates any results flagged as a result of poor precision. Each study consists of 10 samples, which are analyzed by the SWAS laboratory by the same means as the environmental samples. The quality-assurance samples usually are included in laboratory analysis sessions along with environmental samples. The analytical results are then reported to the NWRI. Results of analy- 
ses of the quality-assurance samples by the SWAS laboratory for the period 1994 through 2000 are shown in table 8 (at end of report).

\section{WATER-QUALITY DATA OF SOIL-WATER SAMPLES}

Water-quality data of soil-water samples collected from Paine Run watershed are shown in table 9; data from Staunton River watershed are shown in table 10; and data from Piney River watershed are shown in table 11 (tables 9-11 at end of report).

\section{REFERENCES CITED}

Gathright, II, T.M., 1976, Geology of the Shenandoah National Park, Virginia: Virginia Division of Mineral Resources Bulletin 86, 93 p.

McAvoy, D.C., Santore, R.C., Shosa, J.D., and Driscoll, C.T., 1992, Comparison between Pyrocatechol Violet and 8-Hydroxyquinoline procedures for determining aluminum fractions: Soil Science Society of America Journal, v. 56, no. 2, p. 449-455.

University of Virginia, July 15, 1996, Laboratory procedure manual: University of Virginia, accessed December 6, 2000, at URL http://wsrv.clas.virginia.edu/ swasftp/ docs/9509_sop/cover.html. 
TABLES 1-11 
Table 1. Locations of lysimeter sites

[', degrees; ', minutes; ", seconds; datum is North American Datum of 1927]

\begin{tabular}{|c|c|c|}
\hline $\begin{array}{l}\text { Lysimeter } \\
\text { site }\end{array}$ & Latitude & Longitude \\
\hline \multicolumn{3}{|c|}{ Paine Run watershed } \\
\hline 1 & $38^{\circ} 11^{\prime} 46^{\prime \prime}$ & $78^{\circ} 47^{\prime} 19^{\prime \prime}$ \\
\hline 2 & $38^{\circ} 11^{\prime} 41^{\prime \prime}$ & $78^{\circ} 47^{\prime} 13^{\prime \prime}$ \\
\hline 3 & $38^{\circ} 11^{\prime} 41^{\prime \prime}$ & $78^{\circ} 47^{\prime} 14^{\prime \prime}$ \\
\hline \multicolumn{3}{|c|}{ Staunton River watershed } \\
\hline 1 & $38^{\circ} 26^{\prime} 42^{\prime \prime}$ & $78^{\circ} 22^{\prime} 38^{\prime \prime}$ \\
\hline 2 & $38^{\circ} 26^{\prime} 42^{\prime \prime}$ & $78^{\circ} 22^{\prime} 35^{\prime \prime}$ \\
\hline 3 & $38^{\circ} 26^{\prime} 43^{\prime \prime}$ & $78^{\circ} 22^{\prime} 34^{\prime \prime}$ \\
\hline \multicolumn{3}{|c|}{ Piney River watershed } \\
\hline 1 & $38^{\circ} 42^{\prime} 06^{\prime \prime}$ & $78^{\circ} 16^{\prime} 02^{\prime \prime}$ \\
\hline 2 & $38^{\circ} 42^{\prime} 05^{\prime \prime}$ & $78^{\circ} 16^{\prime} 03^{\prime \prime}$ \\
\hline 3 & $38^{\circ} 42^{\prime} 07^{\prime \prime}$ & $78^{\circ} 16^{\prime} 02^{\prime \prime}$ \\
\hline
\end{tabular}

Table 2. Laboratory analytical methods

$\left[{ }^{\circ} \mathrm{C}\right.$, degrees Celsius; $\mathrm{Li} / \mathrm{La}$, lithium/lanthanum; $\mu \mathrm{L}$, microliter; $\mathrm{mL}$, milliliter; $\mathrm{mM} \mathrm{Na} 2 \mathrm{CO}_{3}$ /minute, millimolar sodium carbonate per minute; $\mathrm{N}$, normal; $\mathrm{H}_{2} \mathrm{SO}_{4} /$ minute; sulfuric acid per minute; $\mathrm{HCl}$, hydrochloric acid; $\leq$, less than or equal to; minimum analytical detection limits given in microequivalents per liter, except for silica, which is in micromoles per liter and total monomeric aluminum, which is in micrograms per liter]

\begin{tabular}{|c|c|c|c|}
\hline Analyte & $\begin{array}{c}\text { Minimum } \\
\text { analytical } \\
\text { detection limit }\end{array}$ & Instrumentation & Method \\
\hline Specific conductance & None & $\begin{array}{l}\text { YSI Model } 31 \text { Conductivity Bridge; Beck- } \\
\text { man CEL-GO1 cell }\end{array}$ & $\begin{array}{l}\text { Standard conductivity bridge and cell. } \\
\text { Values adjusted to } 25^{\circ} \mathrm{C} \text {. }\end{array}$ \\
\hline $\begin{array}{l}\text { Sodium } \\
\text { Potassium } \\
\text { Calcium } \\
\text { Magnesium }\end{array}$ & $\begin{array}{l}0.06 \\
0.27 \\
0.66 \\
0.30\end{array}$ & $\begin{array}{l}\text { Thermo Jarrel Ash AA/AE Spectrophotome- } \\
\text { ter Model Smith-Hieftje } 22\end{array}$ & $\begin{array}{l}\text { Flame atomic absorption spectrophotom- } \\
\text { etry. Li/La added to aliquot. }\end{array}$ \\
\hline Ammonium & 0.60 & Technicon Autoanalyzer II & $\begin{array}{l}\text { Colorimetric detection by indophenol } \\
\text { blue technique. }\end{array}$ \\
\hline $\begin{array}{l}\text { Chloride } \\
\text { Nitrate } \\
\text { Sulfate }\end{array}$ & $\begin{array}{l}0.24 \\
0.06 \\
0.42\end{array}$ & $\begin{array}{l}\text { Dionex Model } 14 \text { Ion Chromatograph; HPIC } \\
\text { AS4A Separator Column; HPIC AG4A Pre- } \\
\text { Column; AMMS Anion Micro-Membrane } \\
\text { Suppressor }\end{array}$ & $\begin{array}{l}\text { Simultaneous determination by ion chro- } \\
\text { matography. Injection volume: } 200 \mu \mathrm{L} \text {. } \\
\text { Eluent: } 2.2 \mathrm{~mL} 3.4-4.5 \mathrm{mM} \mathrm{Na} \mathrm{CO}_{3} / \\
\text { minute. Regenerant: } 3-4 \mathrm{~mL} 0.035 \mathrm{~N} \\
\mathrm{H}_{2} \mathrm{SO}_{4} / \text { minute. }\end{array}$ \\
\hline Acid-neutralizing capacity & None & $\begin{array}{l}\text { Beckman Psi pH Meter (No. 123114); Corn- } \\
\text { ing Calomel Combination pH Electrode (No. } \\
476530 \text { ) }\end{array}$ & $\begin{array}{l}\text { Two-point Gran titration with } 50-\mathrm{mL} \\
\text { sample aliquot and } 0.005 \mathrm{~N} \mathrm{HCl} \text { titrant. } \\
\text { Within-aliquot stability }(\leq 0.01 \text { units/ } \\
\text { min.) obtained for endpoint determina- } \\
\text { tions. }\end{array}$ \\
\hline Silica & 2.1 & Technicon Autoanalyzer II & $\begin{array}{l}\text { Colorimetric detection by molybdate blue } \\
\text { technique. }\end{array}$ \\
\hline Aluminum, total monomeric & 1.2 & Technicon Autoanalyzer II & $\begin{array}{l}\text { Colorimetric detection with open-system } \\
\text { samples by pyrocatechol violet technique. }\end{array}$ \\
\hline
\end{tabular}


Table 3. Results of ion-difference calculations

[Sums of anion and cation equivalents are in microequivalents per liter, rounded to the nearest whole number; depth, depth of sample below land surface in centimeters; \%, percent; minor differences between the \% ion difference using the original laboratory data and that calculated using the data shown are the result of rounding]

\begin{tabular}{|c|c|c|c|c|}
\hline Site & Depth & $\begin{array}{c}\text { Sum } \\
\text { anions }\end{array}$ & $\begin{array}{c}\text { Sum } \\
\text { cations }\end{array}$ & $\%$ ion difference \\
\hline \multicolumn{5}{|c|}{ Paine Run watershed, sampled 09/22/1999 } \\
\hline 1 & 36 & 183 & 196 & -3.5 \\
\hline 1 & 66 & 226 & 237 & -2.3 \\
\hline 1 & 97 & 487 & 488 & -0.1 \\
\hline 2 & 36 & 135 & 236 & -27 \\
\hline 2 & 66 & 289 & 307 & -3.0 \\
\hline 2 & 97 & 217 & 222 & -1.0 \\
\hline 3 & 36 & 350 & 399 & -6.6 \\
\hline 3 & 97 & 188 & 196 & -1.9 \\
\hline \multicolumn{5}{|c|}{ Paine Run watershed, sampled 01/11/2000 } \\
\hline 1 & 36 & 213 & 238 & -5.7 \\
\hline 2 & 36 & 138 & 221 & -23 \\
\hline 2 & 66 & 231 & 241 & -2.1 \\
\hline 2 & 97 & 155 & 160 & -1.4 \\
\hline 3 & 36 & 305 & 344 & -6.0 \\
\hline 3 & 97 & 148 & 150 & -0.5 \\
\hline \multicolumn{5}{|c|}{ Paine Run watershed, sampled 04/28/2000 } \\
\hline 1 & 97 & 187 & 196 & -2.5 \\
\hline 2 & 36 & 125 & 216 & -27 \\
\hline 2 & 66 & 218 & 229 & -2.3 \\
\hline 2 & 97 & 159 & 167 & -2.4 \\
\hline 3 & 36 & 146 & 153 & -2.3 \\
\hline 3 & 97 & 320 & 358 & -5.6 \\
\hline \multicolumn{5}{|c|}{ Paine Run watershed, sampled 07/28/2000 } \\
\hline 1 & 36 & 603 & 844 & -17 \\
\hline 1 & 97 & 159 & 167 & -2.4 \\
\hline 2 & 66 & 198 & 225 & -6.4 \\
\hline \multicolumn{5}{|c|}{ Staunton River watershed, sampled 09/26/1999 } \\
\hline 1 & 36 & 432 & 472 & -4.4 \\
\hline 2 & 36 & 392 & 413 & -2.6 \\
\hline 2 & 66 & 380 & 391 & -1.5 \\
\hline 2 & 97 & 293 & 303 & -1.6 \\
\hline 3 & 36 & 421 & 440 & -2.2 \\
\hline 3 & 66 & 400 & 420 & -2.4 \\
\hline
\end{tabular}


Table 3. Results of ion-difference calculations-Continued

[Sums of anion and cation equivalents are in microequivalents per liter, rounded to the nearest whole number; depth, depth of sample below land surface in centimeters; \%, percent; minor differences between the \% ion difference using the original laboratory data and that calculated using the data shown are the result of rounding]

\begin{tabular}{|c|c|c|c|c|}
\hline Site & Depth & $\begin{array}{l}\text { Sum } \\
\text { anions }\end{array}$ & $\begin{array}{l}\text { Sum } \\
\text { cations }\end{array}$ & $\%$ ion difference \\
\hline \multicolumn{5}{|c|}{ Staunton River watershed, sampled 01/11/2000 } \\
\hline 1 & 36 & 272 & 285 & -2.4 \\
\hline 1 & 66 & 305 & 322 & -2.8 \\
\hline 2 & 66 & 243 & 249 & -1.2 \\
\hline 2 & 97 & 209 & 211 & -0.5 \\
\hline 3 & 66 & 281 & 284 & -0.5 \\
\hline \multicolumn{5}{|c|}{ Staunton River watershed, sampled 04/29/2000 } \\
\hline 1 & 36 & 285 & 297 & -2.2 \\
\hline 1 & 66 & 242 & 257 & -3.0 \\
\hline 1 & 97 & 320 & 398 & -11 \\
\hline 2 & 36 & 292 & 314 & -3.7 \\
\hline 2 & 66 & 249 & 256 & -1.4 \\
\hline 2 & 97 & 183 & 189 & -1.6 \\
\hline 3 & 36 & 267 & 275 & -1.4 \\
\hline \multicolumn{5}{|c|}{ Staunton River watershed, sampled 07/28/2000 } \\
\hline 2 & 36 & 560 & 552 & 0.7 \\
\hline \multicolumn{5}{|c|}{ Piney River watershed, sampled 10/18/1999 } \\
\hline 1 & 36 & 344 & 402 & -7.7 \\
\hline 1 & 66 & 350 & 392 & -5.7 \\
\hline 1 & 97 & 2,779 & 3,346 & -9.3 \\
\hline 2 & 36 & 438 & 456 & -2.0 \\
\hline 2 & 97 & 1,210 & 1,519 & -11 \\
\hline 3 & 36 & 229 & 314 & -16 \\
\hline 3 & 66 & 836 & 866 & -1.8 \\
\hline 3 & 97 & 304 & 313 & -1.5 \\
\hline
\end{tabular}

Piney River watershed, sampled 01/11/2000

\begin{tabular}{lllll}
\hline 1 & 36 & 309 & 346 & -5.7 \\
1 & 66 & 322 & 337 & -2.3 \\
1 & 97 & 457 & 493 & -3.8 \\
2 & 36 & 351 & 380 & -3.9 \\
2 & 97 & 650 & 947 & -19 \\
3 & 36 & 182 & 241 & -14 \\
3 & 97 & 265 & 276 & -2.1 \\
\hline
\end{tabular}

Piney River watershed, sampled 04/29/2000

\begin{tabular}{lllll}
\hline 1 & 36 & 324 & 363 & -5.6 \\
1 & 66 & 290 & 306 & -2.7 \\
1 & 97 & 381 & 417 & -4.5
\end{tabular}


Table 3. Results of ion-difference calculations-Continued

[Sums of anion and cation equivalents are in microequivalents per liter, rounded to the nearest whole number; depth, depth of sample below land surface in centimeters; \%, percent; minor differences between the \% ion difference using the original laboratory data and that calculated using the data shown are the result of rounding]

\begin{tabular}{ccccc}
\hline Site & Depth & $\begin{array}{c}\text { Sum } \\
\text { anions }\end{array}$ & $\begin{array}{c}\text { Sum } \\
\text { cations }\end{array}$ & \% ion difference \\
\hline 2 & 36 & 326 & 335 & -1.4 \\
2 & 97 & 429 & 485 & -6.1 \\
2 & 36 & 192 & 257 & -15 \\
3 & 66 & 383 & 403 & -2.6 \\
3 & 97 & 259 & 261 & -0.5 \\
\hline 1 & Piney River watershed, sampled 07/28/2000 & \\
\hline 1 & 36 & 372 & 440 & -8.5 \\
1 & 66 & 314 & 322 & -1.1 \\
2 & 97 & 440 & 492 & -3.1 \\
2 & 36 & 336 & 357 & -6.0 \\
3 & 97 & 677 & 763 & -13 \\
\hline & 66 & 4,226 & 5,441 & -12 \\
\hline
\end{tabular}


Table 4. Results of analysis of natural-matrix reference samples (FN09 and FN10)

[All concentrations in microequivalents per liter, except silica, which is in micromoles per liter, and aluminum, which is in micrograms per liter; \%, percent; $\mathrm{Na}^{+}$, sodium; $\mathrm{K}^{+}$, potassium; $\mathrm{Ca}^{2+}$, calcium; $\mathrm{Mg}^{2+}$, magnesium; $\mathrm{Cl}^{-}$, chloride; $\mathrm{NO}_{3}{ }^{-}$, nitrate; $\mathrm{SO}_{4}{ }^{2-}$, sulfate; $\mathrm{SiO}_{2}$, silica; $\mathrm{Al}$, total monomeric aluminum; target, the mean of the median concentration values reported for each interlaboratory round-robin study in which the natural-matrix reference sample was included (minimum of three round-robin studies) prior to use by the University of Virginia Shenandoah Watershed Study laboratory]

\begin{tabular}{|c|c|c|c|c|c|c|c|c|c|}
\hline Summary statistics & $\mathrm{Na}^{+}$ & $\mathrm{K}^{+}$ & $\mathrm{Ca}^{2+}$ & $\mathrm{Mg}^{2+}$ & $\mathrm{Cl}^{-}$ & $\mathrm{NO}_{3}^{-}$ & $\mathrm{SO}_{4}{ }^{2-}$ & $\mathrm{SiO}_{2}$ & Al \\
\hline \multicolumn{10}{|c|}{ FN09 } \\
\hline Number of samples & 1 & 2 & 1 & 2 & 14 & 15 & 15 & 19 & 8 \\
\hline Mean & 110 & 11.5 & 254 & 65.6 & 114 & 12.7 & 137 & 71.3 & 24.6 \\
\hline Standard deviation & 0.00 & 0.10 & 0.00 & 0.08 & 0.87 & 0.08 & 0.87 & 0.64 & 2.80 \\
\hline Target & 113 & 12.0 & 251 & 64.2 & 112 & 17.1 & 132 & 67.6 & 13.0 \\
\hline$\%$ difference from target & -2.7 & -4.2 & 1.2 & 2.2 & 1.8 & -25.7 & 3.8 & 5.5 & 89.2 \\
\hline \multicolumn{10}{|c|}{ FN10 } \\
\hline Number of samples & 2 & 2 & 2 & 2 & 14 & 15 & 14 & 16 & 6 \\
\hline Mean & 24.6 & 8.0 & 88.4 & 24.5 & 9.0 & 14.9 & 125 & 61.0 & 163 \\
\hline Standard deviation & 0.30 & 0.01 & 1.00 & 0.12 & 0.18 & 0.11 & 0.35 & 0.45 & 8.56 \\
\hline Target & 24.8 & 8.2 & 90.8 & 23.9 & 8.5 & 14.3 & 118 & 57.6 & 158 \\
\hline$\%$ difference from target & -0.8 & -2.4 & -2.6 & 2.5 & 5.9 & 4.2 & 5.9 & 5.9 & 3.2 \\
\hline
\end{tabular}

Table 5. Results of analysis of synthetic-matrix reference samples (EPA1)

[All concentrations in microequivalents per liter; \%, percent; $\mathrm{NO}_{3}{ }^{-}$, nitrate; $\mathrm{NH}_{4}{ }^{+}$, ammonium; target, the theoretical concentration value]

\begin{tabular}{lcc}
\hline Summary statistics & $\mathbf{N O}_{\mathbf{3}}{ }^{-}$ & $\mathbf{N H}_{\mathbf{4}}{ }^{+}$ \\
\hline Number of samples & 15 & 20 \\
Mean & 12.8 & 9.8 \\
Standard deviation & 0.13 & 0.40 \\
Target & 12.9 & 10.7 \\
\% difference from target & -0.8 & -8.4 \\
\hline
\end{tabular}


Table 6. Results of laboratory-split analyses of selected soil-water samples

[All concentrations in microequivalents per liter; depth, depth of sample below land surface in centimeters; n.a., not analyzed; b.d., below minimum analytical detection limit; $\mathrm{Na}^{+}$, sodium; $\mathrm{K}^{+}$, potassium; $\mathrm{Ca}^{2+}$, calcium; $\mathrm{Mg}^{2+}$, magnesium; $\mathrm{NH}_{4}{ }^{+}$, ammonium; $\mathrm{Cl}^{-}$, chloride; $\mathrm{NO}_{3}{ }^{-}$, nitrate; $\mathrm{SO}_{4}{ }^{2-}$, sulfate]

\begin{tabular}{|c|c|c|c|c|c|c|c|c|c|c|}
\hline Site & Depth & $\begin{array}{c}\text { Date } \\
\text { sampled }\end{array}$ & $\mathrm{Na}^{+}$ & $\mathrm{K}^{+}$ & $\mathrm{Ca}^{2+}$ & $\mathrm{Mg}^{2+}$ & $\mathrm{NH}_{4}^{+}$ & $\mathrm{Cl}^{-}$ & $\mathrm{NO}_{3}^{-}$ & $\mathrm{SO}_{4}{ }^{2-}$ \\
\hline \multicolumn{11}{|c|}{ Samples collected from Paine Run watershed } \\
\hline 3 & 97 & $09 / 22 / 99$ & 25.9 & 81.7 & 38.9 & 49.1 & n.a. & n.a. & n.a. & n.a. \\
\hline 3 & 97 & 09/22/99 & 27.6 & 84.7 & 40.2 & 47.0 & n.a. & n.a. & n.a. & n.a. \\
\hline 3 & 97 & 01/11/00 & n.a. & n.a. & n.a. & n.a. & n.a. & 19.6 & 6.6 & 115 \\
\hline 3 & 97 & $01 / 11 / 00$ & n.a. & n.a. & n.a. & n.a. & n.a. & 19.5 & 6.5 & 115 \\
\hline 3 & 36 & $04 / 28 / 00$ & n.a. & n.a. & n.a. & n.a. & b.d. & n.a. & n.a. & n.a. \\
\hline 3 & 36 & $04 / 28 / 00$ & n.a. & n.a. & n.a. & n.a. & b.d. & n.a. & n.a. & n.a. \\
\hline \multicolumn{11}{|c|}{ Samples collected from Staunton River watershed } \\
\hline 2 & 66 & $09 / 26 / 99$ & n.a. & n.a. & n.a. & n.a. & n.a. & 40.3 & b.d. & 181 \\
\hline 2 & 66 & 09/26/99 & n.a. & n.a. & n.a. & n.a. & n.a. & 40.1 & 0.15 & 181 \\
\hline 1 & 36 & 01/11/00 & 31.8 & 18.0 & 141 & 93.5 & n.a. & n.a. & n.a. & n.a. \\
\hline 1 & 36 & 01/11/00 & 34.1 & 18.9 & 142 & 92.2 & n.a. & n.a. & n.a. & n.a. \\
\hline 3 & 97 & $04 / 29 / 00$ & n.a. & n.a. & n.a. & n.a. & 1.3 & n.a. & n.a. & n.a. \\
\hline 3 & 97 & 04/29/00 & n.a. & n.a. & n.a. & n.a. & 1.3 & n.a. & n.a. & n.a. \\
\hline \multicolumn{11}{|c|}{ Samples collected from Piney River watershed } \\
\hline 1 & 36 & $10 / 18 / 99$ & 28.8 & 77.3 & 174 & 122 & n.a. & n.a. & n.a. & n.a. \\
\hline 1 & 36 & $10 / 18 / 99$ & 30.7 & 76.0 & 174 & 116 & n.a. & n.a. & n.a. & n.a. \\
\hline 3 & 97 & $10 / 18 / 99$ & n.a. & n.a. & n.a. & n.a. & n.a. & 39.4 & 59.1 & 226 \\
\hline 3 & 97 & $10 / 18 / 99$ & n.a. & n.a. & n.a. & n.a. & n.a. & 39.3 & 58.9 & 225 \\
\hline 2 & 66 & $04 / 29 / 00$ & 46.3 & 22.0 & 285 & 132 & n.a. & n.a. & n.a. & n.a. \\
\hline 2 & 66 & $04 / 29 / 00$ & 47.6 & 22.9 & 278 & 130 & n.a. & n.a. & n.a. & n.a. \\
\hline
\end{tabular}


Table 7. Results of process-blank analyses

[All concentrations in microequivalents per liter, except silica, which is in micromoles per liter, and aluminum, which is in micrograms per liter; $\mathrm{Na}^{+}$, sodium; $\mathrm{K}^{+}$, potassium; $\mathrm{Ca}^{2+}$, calcium; $\mathrm{Mg}^{2+}$, magnesium; $\mathrm{NH}_{4}{ }^{+}$, ammonium; $\mathrm{Cl}^{-}$, chloride; $\mathrm{NO}_{3}{ }^{-}$, nitrate; $\mathrm{SO}_{4}{ }^{2-}$, sulfate, ANC, acid-neutralizing capacity; $\mathrm{SiO}_{2}$, silica; $\mathrm{Al}$, total monomeric aluminum]

\begin{tabular}{|c|c|c|c|c|c|c|c|c|c|c|c|}
\hline Summary statistics & $\mathrm{Na}^{+}$ & $\mathrm{K}^{+}$ & $\mathrm{Ca}^{2+}$ & $\mathrm{Mg}^{2+}$ & $\mathrm{NH}_{4}^{+}$ & $\mathrm{Cl}^{-}$ & $\mathrm{NO}_{3}^{-}$ & $\mathrm{SO}_{4}^{2-}$ & ANC & $\mathrm{SiO}_{2}$ & Al \\
\hline Number of samples & 4 & 4 & 4 & 4 & 4 & 4 & 4 & 4 & 4 & 4 & 4 \\
\hline Mean & -0.04 & -0.01 & -0.10 & 0.08 & 0.01 & 0.25 & -0.02 & 0.83 & -1.9 & 0.31 & 2.4 \\
\hline Minimum analytical detection limit & 0.06 & 0.27 & 0.66 & 0.30 & 0.60 & 0.24 & 0.06 & 0.42 & none & 2.1 & 1.2 \\
\hline Standard deviation & 0.06 & 0.15 & 0.20 & 0.15 & 0.20 & 0.13 & 0.02 & 0.14 & 1.56 & 0.30 & 1.16 \\
\hline Standard error & 0.03 & 0.07 & 0.10 & 0.08 & 0.10 & 0.07 & 0.01 & 0.07 & 0.78 & 0.15 & 0.58 \\
\hline
\end{tabular}

Table 8. Results for National Water Research Institute interlaboratory quality-assurance studies

[A, acceptable; N, no results; 1, although no results are flagged, ranking indicates a slight bias low; 2, although no results are flagged, ranking indicates a slight bias low; after these results were submitted, the ion chromatography column used for chloride analyses was replaced; 3 , acceptable, except for high on 1 out of 10 samples; 4, although no results are flagged, ranking indicates a slight bias high; 5, flagged very high on 1 out of 10 samples, due to a calculation error made after analysis; 6, 2 out of 10 samples flagged: one extremely low, one low; 7, 2 out of 10 samples flagged: both very low; 8, flagged extremely low on 1 out of 10 samples; $\mathrm{SC}$, specific conductance; $\mathrm{Na}^{+}$, sodium; $\mathrm{K}^{+}$, potassium; $\mathrm{Ca}^{2+}$, calcium; $\mathrm{Mg}^{2+}$, magnesium; $\mathrm{NH}_{4}^{+}$, ammonium; $\mathrm{Cl}^{-}$, chloride; $\mathrm{NO}_{3}{ }^{-}$, nitrate; $\mathrm{SO}_{4}^{2-}$, sulfate, ANC, acid-neutralizing capacity; $\mathrm{SiO}_{2}$, silica ]

\begin{tabular}{|c|c|c|c|c|c|c|c|c|c|c|c|c|}
\hline Study date & $\mathrm{pH}$ & sc & $\mathrm{Na}^{+}$ & $\mathrm{K}^{+}$ & $\mathrm{Ca}^{2+}$ & $\mathrm{Mg}^{2+}$ & $\mathrm{NH}_{4}{ }^{+}$ & $\mathrm{Cl}^{-}$ & $\mathrm{NO}_{3}{ }^{-}$ & $\mathrm{SO}_{4}{ }^{2-}$ & ANC & $\mathrm{SiO}_{2}$ \\
\hline $05 / 10 / 94$ & $\mathrm{~A}$ & $\mathrm{~A}$ & $\bar{A}$ & A & $\mathrm{A}$ & $\mathrm{A}$ & A & $\mathrm{A}$ & $\mathrm{A}$ & $\mathrm{A}$ & $\mathrm{N}$ & $\mathrm{A}$ \\
\hline $01 / 15 / 95$ & A & 1 & A & A & A & 4 & A & 2 & A & A & A & 3 \\
\hline $09 / 05 / 95$ & A & A & A & A & A & A & $\mathrm{N}$ & A & A & A & A & A \\
\hline 09/01/96 & A & A & 5 & A & A & A & A & A & A & A & A & A \\
\hline 09/02/97 & A & A & A & A & A & A & A & A & A & A & A & A \\
\hline 09/01/98 & A & A & A & A & A & A & 6 & A & A & A & A & A \\
\hline 09/01/99 & A & A & A & A & A & A & 7 & A & A & A & A & A \\
\hline $08 / 28 / 00$ & A & A & A & A & A & A & A & A & A & A & A & 8 \\
\hline
\end{tabular}


Table 9. Water-quality data of soil-water samples collected from Paine Run watershed, Shenandoah National Park, Virginia, 1999-2000

[Depth, depth of sample below land surface in centimeters; SC, specific conductance in microsiemens per centimeter at $25^{\circ} \mathrm{C}$; all concentrations in microequivalents per liter, except for silica, which is in micromoles per liter and total monomeric aluminum, which is in micrograms per liter; b.d., below minimum analytical detection limit; -, insufficient sample for analysis; $\mathrm{Na}^{+}$, sodium; $\mathrm{K}^{+}$, potassium; $\mathrm{Ca}^{2+}$, calcium; $\mathrm{Mg}^{2+}$, magnesium; $\mathrm{NH}_{4}{ }^{+}$, ammonium; $\mathrm{Cl}^{-}$, chloride; $\mathrm{NO}_{3}{ }^{-}$, nitrate; $\mathrm{SO}_{4}{ }^{2-}$, sulfate, $\mathrm{ANC}$, acid-neutralizing capacity; $\mathrm{SiO}_{2}$, silica; $\mathrm{Al}$, total monomeric aluminum]

\begin{tabular}{|c|c|c|c|c|c|c|c|c|c|c|c|c|c|}
\hline Site & Depth & SC & $\mathrm{Na}^{+}$ & $\mathrm{K}^{+}$ & $\mathrm{Ca}^{2+}$ & $\mathrm{Mg}^{2+}$ & $\mathrm{NH}_{4}^{+}$ & $\mathrm{Cl}^{-}$ & $\mathrm{NO}_{3}^{-}$ & $\mathrm{SO}_{4}{ }^{2-}$ & ANC & $\mathrm{SiO}_{2}$ & Al \\
\hline \multicolumn{14}{|c|}{ Lysimeters sampled 09/22/1999 } \\
\hline 1 & 36 & 24.8 & 28.6 & 52.2 & 54.5 & 59.9 & 0.67 & 6.20 & 4.8 & 123 & 48.6 & 85.7 & 82.1 \\
\hline 1 & 66 & 33.0 & 29.2 & 78.6 & 66.9 & 61.7 & b.d. & 26.6 & 15.3 & 157 & 27.2 & 103 & 5.2 \\
\hline 1 & 97 & 66.0 & 46.1 & 143 & 135 & 164 & b.d. & 49.0 & 309 & 111 & 17.2 & 117 & 48.0 \\
\hline 2 & 36 & 30.3 & 24.4 & 49.4 & 111 & 50.0 & 0.89 & 7.50 & 0.06 & 111 & 15.7 & 101 & 562 \\
\hline 2 & 66 & 41.0 & 26.8 & 78.9 & 126 & 74.4 & b.d. & 39.7 & 0.87 & 216 & 32.2 & 137 & 46.6 \\
\hline 2 & 97 & 30.5 & 32.0 & 70.6 & 61.8 & 56.3 & 1.0 & 40.4 & 2.9 & 136 & 38.6 & 126 & 5.9 \\
\hline 3 & 36 & 51.0 & 61.5 & 125 & 98.7 & 114 & b.d. & 55.8 & 0.06 & 258 & 35.6 & 169 & 147 \\
\hline 3 & 66 & - & 92.1 & 77.5 & 65.4 & 60.1 & 1.6 & 31.5 & 1.6 & 172 & - & 149 & 25.7 \\
\hline 3 & 97 & 27.0 & 25.9 & 81.7 & 38.9 & 49.1 & b.d. & 19.0 & 21.9 & 117 & 30.6 & 95.8 & 41.3 \\
\hline
\end{tabular}

Lysimeters sampled 01/11/2000

\begin{tabular}{cccccccccccccc}
\hline 1 & 36 & - & - & - & - & - & - & - & - & - & - & - & - \\
1 & 66 & - & - & - & - & - & - & - & - & - & - & - & - \\
1 & 97 & 32.3 & 23.2 & 62.8 & 50.4 & 68.8 & 33.1 & 20.6 & 34.4 & 139 & 18.6 & 80.2 & 8.7 \\
2 & 36 & 30.2 & 18.0 & 45.7 & 104 & 47.7 & 6.0 & 11.4 & 0.47 & 126 & 0.74 & 64.7 & 393 \\
2 & 66 & 33.7 & 18.9 & 56.4 & 110 & 55.8 & b.d. & 38.4 & 0.95 & 185 & 7.2 & 77.8 & 109 \\
2 & 97 & 21.5 & 19.4 & 48.3 & 54.3 & 37.4 & b.d. & 26.6 & 2.8 & 110 & 15.3 & 75.9 & 32.0 \\
3 & 36 & 46.5 & 39.2 & 115 & 78.3 & 110 & b.d. & 58.7 & b.d. & 239 & 7.5 & 116 & 258 \\
3 & 66 & - & - & - & - & - & - & - & - & - & - & - & - \\
3 & 97 & 22.1 & 20.0 & 59.8 & 24.7 & 45.1 & b.d. & 19.6 & 6.6 & 115 & 7.2 & 77.2 & 93.5 \\
\hline
\end{tabular}

Lysimeters sampled 04/28/2000

\begin{tabular}{cccccccccccccc}
\hline 1 & 36 & - & - & - & - & - & - & - & - & - & - & - & - \\
1 & 66 & - & - & - & - & - & - & - & - & - & - & - & - \\
1 & 97 & 27.5 & 21.9 & 62.6 & 46.2 & 64.9 & 0.83 & 20.4 & 29.2 & 128 & 8.6 & 81.4 & 44.5 \\
2 & 36 & 28.6 & 15.0 & 43.5 & 113 & 43.9 & b.d. & 15.8 & 0.08 & 103 & 6.2 & 66.5 & 496 \\
2 & 66 & 33.1 & 20.1 & 60.1 & 101 & 47.5 & b.d. & 34.0 & 1.8 & 175 & 7.2 & 81.0 & 119 \\
2 & 97 & 23.5 & 24.7 & 53.7 & 53.4 & 35.1 & b.d. & 36.8 & 0.06 & 105 & 17.2 & 80.2 & 37.8 \\
3 & 36 & 22.2 & 21.6 & 70.3 & 21.5 & 39.4 & b.d. & 28.3 & 1.1 & 106 & 10.4 & 88.9 & 67.7 \\
3 & 66 & - & - & - & - & - & - & - & - & - & - & - & - \\
3 & 97 & 49.9 & 44.6 & 146 & 71.6 & 96.0 & b.d. & 73.9 & 0.06 & 236 & 10.4 & 131 & 246 \\
\hline
\end{tabular}

Lysimeters sampled 07/28/2000

\begin{tabular}{cccccccccccccc}
\hline 1 & 36 & 75.9 & 26.3 & 82.0 & 366 & 85.6 & 284 & 17.1 & 0.45 & 77.0 & 508 & 61.1 & 20.7 \\
1 & 66 & - & - & - & - & - & - & - & - & - & - & - & - \\
1 & 97 & 24.3 & 31.8 & 56.4 & 35.6 & 42.9 & b.d. & 22.2 & b.d. & 116 & 20.0 & 110 & 9.1 \\
2 & 36 & - & - & - & - & - & - & - & - & - & - & - & - \\
2 & 66 & 30.5 & 29.8 & 57.5 & 93.7 & 44.2 & b.d. & 14.0 & 5.0 & 160 & 18.6 & 109 & 37.7 \\
2 & 97 & - & - & - & - & - & - & - & - & - & - & - & - \\
3 & 36 & - & - & - & - & - & - & - & - & - & - & - & - \\
3 & 66 & - & - & - & - & - & - & - & - & - & - & - & - \\
3 & 97 & - & - & - & - & - & - & - & - & - & - & - & - \\
\hline
\end{tabular}


Table 10. Water-quality data of soil-water samples collected from Staunton River watershed, Shenandoah National Park, Virginia, 1999-2000

[Depth, depth of sample below land surface in centimeters; $\mathrm{SC}$, specific conductance in microsiemens per centimeter at $25^{\circ} \mathrm{C}$; all concentrations in microequivalents per liter, except for silica, which is in micromoles per liter and total monomeric aluminum, which is in micrograms per liter; b.d., below minimum analytical detection limit; -, insufficient sample for analysis; $\mathrm{Na}^{+}$, sodium; $\mathrm{K}^{+}$, potassium; $\mathrm{Ca}^{2+}$, calcium; $\mathrm{Mg}^{2+}$, magnesium; $\mathrm{NH}_{4}{ }^{+}$, ammonium; $\mathrm{Cl}^{-}$, chloride; $\mathrm{NO}_{3}{ }^{-}$, nitrate; $\mathrm{SO}_{4}{ }^{2-}$, sulfate, $\mathrm{ANC}$, acid-neutralizing capacity; $\mathrm{SiO} 2$, silica; $\mathrm{Al}$, total monomeric aluminum]

\begin{tabular}{|c|c|c|c|c|c|c|c|c|c|c|c|c|c|}
\hline Site & Depth & sc & $\mathrm{Na}^{+}$ & $\mathrm{K}^{+}$ & $\mathrm{Ca}^{2+}$ & $\mathrm{Mg}^{2+}$ & $\mathrm{NH}_{4}^{+}$ & $\mathrm{Cl}^{-}$ & $\mathrm{NO}_{3}^{-}$ & $\mathrm{SO}_{4}{ }^{2-}$ & ANC & $\mathrm{SiO}_{2}$ & Al \\
\hline \multicolumn{14}{|c|}{ Lysimeters sampled 09/26/1999 } \\
\hline 1 & 36 & 50.4 & 78.1 & 23.3 & 233 & 137 & 0.67 & 21.9 & 0.60 & 216 & 194 & 99.6 & 6.4 \\
\hline 1 & 66 & - & 134 & 22.9 & 273 & 153 & 0.94 & 47.8 & 3.3 & 140 & - & 195 & 17.5 \\
\hline 1 & 97 & - & - & - & - & - & - & - & - & - & - & - & - \\
\hline 2 & 36 & 48.8 & 43.7 & 26.8 & 230 & 112 & b.d. & 5.7 & b.d. & 271 & 115 & 66.8 & 3.9 \\
\hline 2 & 66 & 45.4 & 49.5 & 38.6 & 202 & 101 & b.d. & 40.3 & b.d. & 181 & 159 & 85.5 & 3.2 \\
\hline 2 & 97 & 34.1 & 59.9 & 18.5 & 148 & 75.4 & 1.1 & 37.1 & 4.0 & 112 & 140 & 109 & 4.1 \\
\hline 3 & 36 & 48.3 & 77.7 & 25.5 & 229 & 106 & 1.4 & 14.4 & 1.0 & 205 & 201 & 111 & 3.3 \\
\hline 3 & 66 & 47.2 & 84.9 & 32.9 & 201 & 99.9 & 1.3 & 38.2 & 4.3 & 164 & 194 & 124 & 11.7 \\
\hline 3 & 97 & - & - & - & - & - & - & - & - & - & - & - & - \\
\hline \multicolumn{14}{|c|}{ Lysimeters sampled 01/11/2000 } \\
\hline 1 & 36 & 34.6 & 31.8 & 18.0 & 141 & 93.5 & 0.61 & 27.9 & b.d. & 183 & 60.7 & 47.4 & 3.8 \\
\hline 1 & 66 & 34.1 & 50.6 & 10.1 & 168 & 92.7 & 0.89 & 18.4 & 0.40 & 121 & 165 & 110 & 4.2 \\
\hline 1 & 97 & - & - & - & - & - & - & - & - & - & - & - & - \\
\hline 2 & 36 & - & - & - & - & - & - & - & - & - & - & - & - \\
\hline 2 & 66 & 30.3 & 25.2 & 18.6 & 139 & 66.0 & b.d. & 11.6 & 0.27 & 146 & 85.4 & 60.0 & 2.6 \\
\hline 2 & 97 & 24.8 & 34.8 & 9.5 & 110 & 56.1 & b.d. & 16.9 & b.d. & 115 & 76.9 & 87.5 & 4.2 \\
\hline 3 & 36 & - & - & - & - & - & - & - & - & - & - & - & - \\
\hline 3 & 66 & 33.9 & 37.7 & 22.5 & 152 & 71.7 & b.d. & 15.1 & 6.6 & 159 & 100 & 82.4 & 4.1 \\
\hline 3 & 97 & - & - & - & - & - & - & - & - & - & - & - & - \\
\hline \multicolumn{14}{|c|}{ Lysimeters sampled 04/29/2000 } \\
\hline 1 & 36 & 34.4 & 26.5 & 20.5 & 176 & 74.3 & b.d. & 17.2 & 3.9 & 165 & 98.6 & 57.6 & 9.8 \\
\hline 1 & 66 & 31.1 & 31.4 & 23.6 & 139 & 63.3 & b.d. & 16.2 & 9.0 & 153 & 63.6 & 75.1 & b.d. \\
\hline 1 & 97 & 43.8 & 40.9 & 20.0 & 242 & 89.5 & 5.8 & 25.7 & 51.2 & 138 & 105 & 93.0 & b.d. \\
\hline 2 & 36 & 36.7 & 23.1 & 23.3 & 180 & 88.0 & b.d. & 18.7 & b.d. & 192 & 80.6 & 48.2 & 2.2 \\
\hline 2 & 66 & 23.4 & 26.8 & 21.6 & 143 & 64.2 & b.d. & 19.5 & 17.1 & 137 & 75.4 & 64.5 & b.d. \\
\hline 2 & 97 & 28.5 & 32.2 & 10.1 & 97.7 & 49.1 & b.d. & 11.6 & b.d. & 114 & 57.2 & 82.0 & b.d. \\
\hline 3 & 36 & 34.5 & 32.7 & 19.9 & 134 & 86.4 & 1.3 & 17.9 & 22.9 & 169 & 56.9 & 49.8 & b.d. \\
\hline 3 & 66 & 34.7 & 45.7 & 11.9 & 167 & 88.0 & -- & 29.7 & 0.18 & 115 & 152 & 107 & 3.1 \\
\hline 3 & 97 & - & - & - & - & - & - & - & - & - & - & - & - \\
\hline
\end{tabular}

Lysimeters sampled $07 / 28 / 2000$

\begin{tabular}{|c|c|c|c|c|c|c|c|c|c|c|c|c|c|}
\hline 1 & 36 & - & - & - & - & - & - & - & - & - & - & - & - \\
\hline 1 & 66 & - & - & - & - & - & - & - & - & - & - & - & - \\
\hline 1 & 97 & - & - & - & - & - & - & - & - & - & - & - & - \\
\hline 2 & 36 & 69.7 & 65.9 & 43.1 & 223 & 106 & 114 & 29.6 & 9.6 & 192 & 328 & 103 & 22.5 \\
\hline 2 & 66 & - & - & - & - & - & - & - & - & - & - & - & - \\
\hline 2 & 97 & - & - & - & - & - & - & - & - & - & - & - & - \\
\hline 3 & 36 & - & - & - & - & - & - & - & - & - & - & - & - \\
\hline 3 & 66 & - & - & - & - & - & - & - & - & - & - & - & - \\
\hline 3 & 97 & - & - & - & - & - & - & - & - & - & - & - & - \\
\hline
\end{tabular}


Table 11. Water-quality data of soil-water samples collected from Piney River watershed, Shenandoah National Park, Virginia, 1999-2000

[Depth, depth of sample below land surface in centimeters; $\mathrm{SC}$, specific conductance in microsiemens per centimeter at $25^{\circ} \mathrm{C}$; all concentrations in microequivalents per liter, except for silica, which is in micromoles per liter and total monomeric aluminum, which is in micrograms per liter; b.d., below minimum analytical detection limit; -, insufficient sample for analysis; $\mathrm{Na}^{+}$, sodium; $\mathrm{K}^{+}$, potassium; $\mathrm{Ca}^{2+}$, calcium; $\mathrm{Mg}^{2+}$, magnesium; $\mathrm{NH}_{4}{ }^{+}$, ammonium; $\mathrm{Cl}^{-}$, chloride; $\mathrm{NO}_{3}{ }^{-}$, nitrate; $\mathrm{SO}_{4}{ }^{2-}$, sulfate, $\mathrm{ANC}$, acid-neutralizing capacity; $\mathrm{SiO} 2$, silica; $\mathrm{Al}$, total monomeric aluminum]

\begin{tabular}{|c|c|c|c|c|c|c|c|c|c|c|c|c|c|}
\hline Site & Depth & $\mathrm{SC}$ & $\mathrm{Na}^{+}$ & $\mathrm{K}^{+}$ & $\mathrm{Ca}^{2+}$ & $\mathrm{Mg}^{2+}$ & $\mathrm{NH}_{4}{ }^{+}$ & $\mathrm{Cl}^{-}$ & $\mathrm{NO}_{3}^{-}$ & $\mathrm{SO}_{4}{ }^{2-}$ & ANC & $\mathrm{SiO}_{2}$ & Al \\
\hline \multicolumn{14}{|c|}{ Lysimeters sampled 10/18/1999 } \\
\hline 1 & 36 & 46.4 & 28.8 & 77.3 & 174 & 122 & b.d. & 12.9 & b.d. & 210 & 121 & 97.1 & 15.3 \\
\hline 1 & 66 & 46.3 & 30.8 & 39.8 & 203 & 118 & b.d. & 20.4 & b.d. & 244 & 85.7 & 120 & 1.2 \\
\hline 1 & 97 & 319 & 80.9 & 146 & 1,209 & 405 & 1,505 & 60.1 & b.d. & 143 & 2,576 & 123 & 51.8 \\
\hline 2 & 36 & 56.3 & 56.3 & 64.8 & 181 & 154 & b.d. & 28.3 & b.d. & 335 & 74.4 & 158 & 2.7 \\
\hline 2 & 66 & - & - & - & - & - & - & - & - & - & - & - & - \\
\hline 2 & 97 & 135 & 47.0 & 103 & 940 & 270 & 158 & 31.0 & b.d. & 55.6 & 1,123 & 118 & 34.6 \\
\hline 3 & 36 & 33.8 & 31.7 & 61.4 & 108 & 112 & b.d. & 16.9 & b.d. & 101 & 111 & 86.1 & 89.0 \\
\hline 3 & 66 & 100 & 47.6 & 57.3 & 253 & 189 & 319 & 39.4 & 59.1 & 226 & 511 & 143 & 8.3 \\
\hline 3 & 97 & 39.0 & 36.6 & 46.3 & 95.4 & 134 & b.d. & 33.6 & b.d. & 192 & 77.5 & 141 & 3.0 \\
\hline
\end{tabular}

Lysimeters sampled 01/11/2000

\begin{tabular}{|c|c|c|c|c|c|c|c|c|c|c|c|c|c|}
\hline 1 & 36 & 40.8 & 23.5 & 62.3 & 152 & 108 & b.d. & 30.1 & b.d. & 200 & 78.6 & 78.0 & 49.2 \\
\hline 1 & 66 & 41.8 & 23.4 & 35.0 & 176 & 101 & 1.1 & 27.6 & 0.79 & 235 & 58.6 & 87.0 & 1.2 \\
\hline 1 & 97 & 52.5 & 22.6 & 10.3 & 339 & 119 & 1.3 & 19.3 & 14.6 & 197 & 225 & 122 & 13.6 \\
\hline 2 & 36 & 47.8 & 39.0 & 40.1 & 167 & 132 & 1.8 & 29.4 & b.d. & 293 & 28.2 & 115 & 4.1 \\
\hline 2 & 66 & - & - & - & - & - & - & - & - & - & - & - & - \\
\hline 2 & 97 & 77.7 & 41.6 & 21.7 & 675 & 177 & 32.0 & 21.7 & 4.9 & 156 & 468 & 127 & 21.8 \\
\hline 3 & 36 & 26.5 & 21.0 & 44.1 & 85.7 & 89.0 & 1.4 & 25.4 & 0.71 & 83.1 & 72.9 & 67.9 & 122 \\
\hline 3 & 66 & - & - & - & - & - & - & - & - & - & - & - & - \\
\hline 3 & 97 & 35.3 & 28.4 & 37.0 & 81.8 & 129 & b.d. & 24.3 & 1.3 & 198 & 41.5 & 113 & 6.0 \\
\hline
\end{tabular}

Lysimeters sampled 04/29/2000

\begin{tabular}{|c|c|c|c|c|c|c|c|c|c|c|c|c|c|}
\hline 1 & 36 & 44.2 & 25.1 & 64.6 & 161 & 113 & b.d. & 34.0 & 0.06 & 204 & 86.5 & 86.0 & 22.0 \\
\hline 1 & 66 & 37.6 & 21.7 & 37.1 & 158 & 89.0 & b.d. & 23.4 & 2.1 & 199 & 65.4 & 89.7 & 3.3 \\
\hline 1 & 97 & 46.8 & 24.1 & 13.2 & 288 & 92.0 & b.d. & 27.7 & b.d. & 170 & 184 & 116 & 8.4 \\
\hline 2 & 36 & 42.7 & 31.6 & 40.8 & 144 & 118 & b.d. & 33.7 & b.d. & 251 & 40.4 & 118 & 3.3 \\
\hline 2 & 66 & - & - & - & - & - & - & - & - & - & - & - & - \\
\hline 2 & 97 & 49.2 & 46.3 & 22.0 & 285 & 132 & b.d. & 27.4 & b.d. & 136 & 266 & 125 & 14.2 \\
\hline 3 & 36 & 28.6 & 20.1 & 48.3 & 92.8 & 95.7 & b.d. & 25.4 & 0.27 & 89.8 & 76.5 & 65.5 & 104 \\
\hline 3 & 66 & 48.7 & 33.5 & 24.3 & 198 & 148 & b.d. & 35.9 & b.d. & 241 & 105 & 113 & 2.9 \\
\hline 3 & 97 & 31.8 & 29.1 & 36.0 & 72.4 & 124 & b.d. & 28.1 & 2.6 & 186 & 42.2 & 114 & b.d. \\
\hline
\end{tabular}

Lysimeters sampled 07/28/2000

\begin{tabular}{|c|c|c|c|c|c|c|c|c|c|c|c|c|c|}
\hline 1 & 36 & 48.5 & 39.2 & 58.6 & 176 & 131 & 35.7 & 20.2 & b.d. & 185 & 167 & 124 & 19.4 \\
\hline 1 & 66 & 41.1 & 34.2 & 32.3 & 146 & 79.3 & 30.1 & 19.8 & 34.8 & 175 & 85.0 & 143 & 1.8 \\
\hline 1 & 97 & 58.9 & 36.2 & 27.7 & 301 & 105 & 23.2 & 34.3 & 91.9 & 172 & 142 & 154 & 10.3 \\
\hline 2 & 36 & 48.4 & 46.6 & 37.1 & 147 & 117 & 9.8 & 20.6 & b.d. & 235 & 80.0 & 169 & 4.9 \\
\hline 2 & 66 & - & - & - & - & - & - & - & - & - & - & - & - \\
\hline 2 & 97 & 75.7 & 52.9 & 49.9 & 398 & 171 & 91.1 & 21.3 & 0.21 & 141 & 514 & 172 & 16.6 \\
\hline 3 & 36 & 5,675 & - & - & - & - & - & - & - & - & - & - & - \\
\hline 3 & 66 & 442 & 86.6 & 342 & 2,632 & 974 & 1,407 & 57.7 & 0.26 & 195 & 3,973 & 81.8 & 38.1 \\
\hline 3 & 97 & 94.5 & 45.8 & 148 & 339 & 254 & 80.4 & 29.7 & 138 & 234 & 283 & 125 & 32.0 \\
\hline
\end{tabular}

